\title{
Study of Factors Causing Time and Cost Overrun in Pre-Construction Project (A Case Study of Malaysia)
}

\author{
Muhammad Ilyas' ${ }^{1}$, Jing Li ${ }^{1}$, Irfan Ullah ${ }^{2}$ \\ ${ }^{1}$ Construction Management Department, Dalian University of Technology, Dalian, China \\ ${ }^{2}$ School of Transportation and Logistics, Dalian University of Technology, Dalian, China \\ Email: ilyasbacha_77@mail.dlut.edu.cn, lijing@dlut.edu.cn,irfanktk@mail.dlut.edu.cn
}

How to cite this paper: Ilyas, M., Li, J. and Ullah, I. (2020) Study of Factors Causing Time and Cost Overrun in Pre-Construction Project (A Case Study of Malaysia). World Journal of Engineering and Technology, 8 , 1-12.

https://doi.org/10.4236/wjet.2020.81001

Received: November 5, 2019

Accepted: December 2, 2019

Published: December 5, 2019

Copyright $\odot 2020$ by author(s) and Scientific Research Publishing Inc. This work is licensed under the Creative Commons Attribution International License (CC BY 4.0).

http://creativecommons.org/licenses/by/4.0/

\begin{abstract}
Cost and time overrun are the key troubles of any improvement ventures. These troubles are inflicting the terrible end result in the development of kingdom monetary improvement and thriving. To overcome these problems, the paper examines predominant impact on elements causing the mission postponement and cost. A poll review was led for the situation study embracing various information-gathering procedures. The discoveries from the contextual investigation uncovered that the most persuasive factors in Malaysia: 1) contractor's inappropriate arranging, 2) poor site the board, 3) deficient contractual worker experience, are the most powerful factors. This paper has likewise broken down the normal and least effective of the postpone variables causing task deferral and cost overrun in Malaysia. It likewise infers that there are various measures as per the idea of deferring components to decrease the effect on task postponement and cost overruns in the development industry. There are significant factors in the control of time overrun that would be actual thought related to know and tackle in great impact to improvement rate which may additionally no capacity that be recovered. Thirty (30) massive development extensions in Malaysia were exceptional coping with time overrun at some stage in development. Out of 30 undertakings, 17 (56.67\%) ventures had been introduced by using 1100 days' time overrun, $5(16.67 \%)$ extensions in the middle of a hundred and one to 200 days, $5(16.67 \%)$ ventures 201 to 300 days while three $(10 \%)$ ventures have been deferred for timeframe over 300 days.
\end{abstract}

\section{Keywords}

Cost and Time Overruns, Delay Factors, Construction Industry, Projects Delay 


\section{Introduction}

Construction delays are bound to occur in practically all undertakings because of the miscommunication between contractual workers, subcontractors, property proprietors. Much of the time, development undertakings are postponed on account of the wrong gauge of time and task cost that was at first introduced to the customers or venture proprietors. Postponements and cost overrun are the most widely diagnosed troubles inflicting prolong in the improvement of commercial enterprise in both created and developing nations [1]. An examination by uncovering that the vast majority of ventures had the cost invades from an example of 258 organizations crosswise over 20 nations and 5 landmasses around the globe. By and by, delays happen in each improvement challenge and the extent of these postponements differs essentially from challenge to extend and nation to the nation [2].

The development industry assumes a significant job in contributing to countrywide economic systems around the globe [3]. The development business likewise sways the pace of GDP and work of numerous nations, and hence, the development business is viewed as crucial for the monetary development of a nation [4], and proposed that the development exercises have turned into a huge market pointer since this industry delivers a larger number of items and expends a bigger number of materials than different ventures. The fee overrun is one of the basic problems and requires an excellent deal of research studies and investigation to restrict or minimize the postponement and less variety in spending graphs for future tasks. In a portion of the created nations, the fee overruns outcome could be increased number of actual and the results could be again surpassing $100 \%$ of the underlying undertaking evaluated [5]. The development business is one of the primary divisions to invigorate and give fixings to the improvement of a national economy. Subsequently, it is viewed as that the development has an extraordinary association and assumed huge jobs in the monetary development or reactivation in all nations.

\section{Related Works and Literature Review}

The construction industry is one of the most perplexing, divided enterprises alluded to as calendar and asset driven. In the development industry convenient fruition of venture is a significant foundation of undertaking achievement. Overrun of time is any deferral past the standard development plan. Limiting time and cost is the primary objective in dealing with a development venture. Be that as it may, time delay every now and again happens in all periods of a development venture and therefore builds undertaking complete length [6]. Seldom undertakings square measure finished on agenda [7]. This immediate provides real thought to manage improvement time as every day of postponement contributes plenty of financial gain that is not any longer genuinely recouped. Consequently, various investigations are LED to know the variables inflicting time invade. In the Republic of Indonesia [8] pondered poignant variables on thir- 
ty-one building undertakings and discovered that the foremost nice factors inflicting time overrun square measure configuration changes, poor work profitableness, poor transcription, and quality deficiencies. Through the same investigation of motives for time overruns in improvement extends in urban center [9] situated five chief reasons for deferrals inclusive of Poor website the executives. In Ghana, [10] viewed ground-water tasks and made public that proprietors, settlement or sand professionals positioned unhealthy temp the board, typically regular installment challenges from offices, material acquiring, unhealthy specialized exhibitions and acceleration of cloth fees as predominant issues that may purpose overrun of time. Likewise [11] indicated that the foremost important variables influencing improvement timetables had been financing and installment for finished works, negative agreement the board, modifications in online page conditions, lack of materials, and foolish transcription. As per [12] seventieth of things to try and do skilled time overrun, the regular time postpone tiers from $100 \%$ to half-hour of the primary period of the endeavor. Sudden website stipulations are situated the most clear purpose for timetable defer influencing all out-undertaking terms and value of endeavor [13].

Management got to be ascribed to own been typically flighty climate, growth in material value, misguided material's assessments, elaboration of venture, written agreement worker's absence of land understanding, transient worker's absence of venture sort involvement, and non-recognition with close pointers [14]. In addition, Morris documented 10 elements touching worth overruns in development ventures. These parts are poor mission arrangement, composition, and usage, lengthen in development, offer of crude cloth and hardware by means that of written agreement employee, alternate within the extent of the enterprise. Likewise, examine the aspects of touching development value invades on constructing ventures in the African nation [15]. The author discovered that worth overruns crop up all the additional many the time and are during this means a larger serious issue than time invades in the African nation.

\subsection{Construction Life Cycle}

The basic stages in the venture life cycle comprise four stages which are calculated arranging and practicality studies, structure and building, development, and activity and support. Other than that, the task life cycle can be characterized into five stages which are the attainability stage, plan stage, development stage, abuse stage and disassembling stage. The principal stage is the practicality stage which comprises the issues of affordable, security of laborers along with the development procedure, specialized viewpoints, and essential data for all stages in development (Figure 1).

\subsection{Causes of Overruns}

The author showed that a prominent foundation extends that experience cost and time issues or authoritative debates draw in media consideration as the network adds to financing their conveyance [16]. South Africa, has likewise 


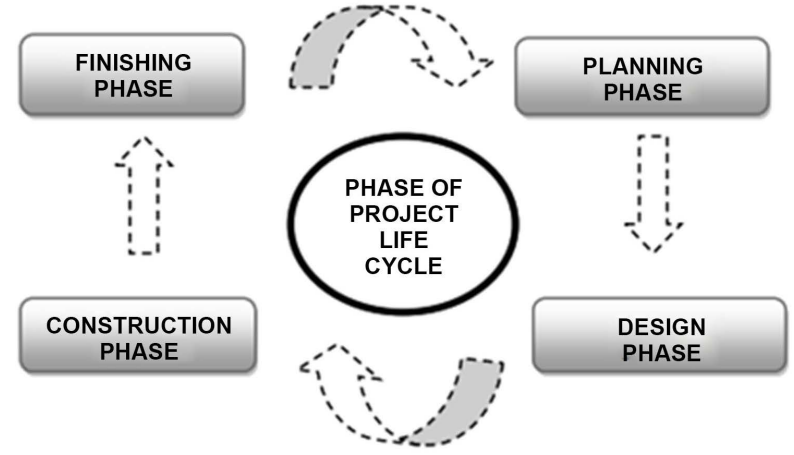

Figure 1. Project life cycle.

encountered some present-day high-quality charge invades in a very few good-sized scale ventures, fashions are the association soccer city area in metropolis worked for R3, 3 billion and encountered a price overrun of fifty-eight [17]. Green point arena in the city center encountered a half value invade [18]. Author has stimulated that daily price overruns for groundwork duties will go between twenty. $4 \%$ for streets, $33.8 \%$ for extensions and burrows and $44.7 \%$ for rail [19], apparently, [20] document surely decrease ranges of common charge (Table 1).

\subsection{Factors Affecting in Cost and Time Overrun}

There are numerous factors that reason time and price invade in development. These aspects have been individual in previous investigations inclusive of a variety of nations. Malaysia [21], directed an overview of large reasons for lengthening in MARA the executive's acquisition development ventures. This investigation was found that the necessary defer causes are profits and cash related troubles looked via temporary workers, contractual workers' bad website the executives and incapable of arranging and reserving through brief workers.

Result suggests the essential ten noteworthy causes are debasement and pay off, political interests, terrible web page the board, delay in web site activation, inflexible demeanor via advisors, extra work without endorsements, visit changes at some stage in execution, gold platting, wellness and wellbeing and constrained get right of entry to locations of work. The author featured that the cost invades to be one in each of the sole difficulties in the execution section of the development venture [22]. In addition, expressed via suggests that [23], the distance of import invades is regularly a clarification for the frustration of a task. However, no longer all creators concur that the frustration is taken into account from one single issue then again a number of settle for their rectangular measure lots of matters inflicting the deferral. In any case, [24] supported those their rectangular measure three great measures to differentiate whether or not or not, the ventures square measure fruitful or not. Tasks have to be compelled to operate the utility, the executives of the challenge and execution of the written agreement employees inside the route of the procedure. Within the alternative hand, 
Table 1. Factors causing time overruns.

\begin{tabular}{|c|c|}
\hline Category & Factors \\
\hline Client & $\begin{array}{l}\text { Money and installment of finished work, Client obstruction, Slow basic } \\
\text { leadership by customers, Unrealistic forced agreement span }\end{array}$ \\
\hline Contractor & $\begin{array}{l}\text { Subcontractors, Site the board, Construction techniques, Improper } \\
\text { arranging, Mistakes during development, Inadequate temporary } \\
\text { worker experience }\end{array}$ \\
\hline Consultant & $\begin{array}{l}\text { Agreement the board, Preparation \& endorsement of drawings, Quality } \\
\text { affirmation/control, Waiting time for endorsement of reviews }\end{array}$ \\
\hline Materials & Nature of material, Shortage in material \\
\hline Labor and equipment & $\begin{array}{l}\text { Work supply, Labor efficiency, Equipment accessibility what's more, } \\
\text { disappointment }\end{array}$ \\
\hline Contractual relationships & $\begin{array}{l}\text { Significant questions and exchanges, Inappropriate hierarchical } \\
\text { structure connecting parties, Lack of correspondence between the } \\
\text { equalities }\end{array}$ \\
\hline External factors & Climate condition, Regulatory changes and construction standard \\
\hline
\end{tabular}

[25] encouraged that the strategy into a fruitful mission success and carry is real estimation, statement time execution, price execution and consequently the rife nature of the development venture.

\section{Methodology}

The essential motivation at the back of this vision was once to exchange the state into focused and dynamic versatile always 2020. As far back as the improvement of business division count on a big job due to the fact that this enterprise can provide higher dedication in countrywide economy and GDP development. Consequently, development enterprise ought to be effective as a long way as conveying task on time besides vitiating any misfortune and the commercial enterprise ought to function suitable, ultimately the United States of America should contend with different created nations on the planet with aspect of accomplishing the inventive and prescient and mission.

For this situation, the scientist has additionally utilized the Relative Importance Index (RII) strategy to distinguish their significance of causes and impact of deferring factors, which is likewise utilized [26]. The survey was sent to three gatherings (customers, advisors and contractual workers) who assume primary jobs in development ventures, where the scale is utilized extending from 1 is not significant and 5 significant. The (RII) was utilized to distinguish which causes are the most critical causes by positioning them into their RII significance esteems. The respondents took an interest in the study wherein ten were recognized as the best factors causing deferral and cost invades from the rundown of 20 [27]. The main 10 most significant elements, which found from the overview in Malaysia development industry, are as per the following:

1) Temporary worker's inappropriate arranging

2) Temporary worker's poor site the executives 
3) Lacking contractual worker experience

4) Lacking customer's account and installments for finished work

5) Issues with subcontractors

6) Deficiency in material

7) Work supply

8) Gear accessibility and disappointment

9) Absence of correspondence between parties

10) Errors during the development arrange

\section{Overrun Factors in Construction Life Cycle}

The motive for this section is to get an everyday view about the factors of time and value overruns that took place in the improvement lifestyles cycle. As indicated by desk (2) beneath, there are 35 variables that were distinct from past investigations and these elements used to be separated into three instructions which are components add to time invaded, cost overrun, and time and cost invade. At that point, these factors were grouped into four degrees entails arranging, plan, development and wrapping up. Just two factors that happened along the development life cycle which comprises of the absence of correspondence among gatherings and change in the extent of the venture. In the mean-time, different variables have happened in various stages (Table 2).

The 30 elements were recorded and a pilot poll study and meetings were directed among three gatherings of master respondents for example customers (6 reacts), venture the executive's specialist (9 reacts) and brief worker (6 reacts) senior faculty (Appendix A). The grasp respondents were noted to rank from 1 to 30 as indicated by means of their conclusions in the positioning structure the place the littler numbers communicate to "higher importance" while the higher. Information assembled was investigated by way of figuring the regular of the score by way of using the recipe:

$$
X=\frac{1}{n} \sum_{i=1}^{n} a_{i}
$$

where,

$$
\begin{aligned}
& X=\text { mean arithmetic, } \\
& n=\text { respondents' quantity, } \\
& a=\text { respondents rating }(i=1 \cdots n) \\
& \qquad S S=\frac{Z^{2} \times P \times(1-P)}{C^{2}}
\end{aligned}
$$

where $S S=$ Sample size,

$Z=Z$ charge (e.g. 1.96 for ninety fifth confidence level),

$P=$ proportion selecting a selection, expressed as a decimal ( 0.50 used for pattern measuring needed), $\mathrm{C}=$ Margin of error (9\%).

It suggests the degree of relationship existing between positioned parts of 2 worlds the essential procedure formula is 
Table 2. Frequency of factors occurred in each phase.

\begin{tabular}{ccccc}
\hline Phase & planning & Design & Construction & Finishing \\
\hline Total & 6 & 10 & 30 & 8 \\
\hline & $e=1-\frac{6 \sum_{i=1}^{n} d_{i}^{2}}{n\left(n^{2}-1\right)}$
\end{tabular}

where $d_{i}=$ the large big difference between the disbursed positions to $X_{i}$ the rank assigned to $Y_{p} \quad I=1,2, \cdots n$ the instance size.

\section{Result and Discussion}

Organized poll summary structured on eighteen elements recovered from Table 3 accustomed be directed among the varsity of Project Management Consultants (PMC). A total of forty-five poll sets had been disseminated and thirty-seven reactions were gotten that framed $82.22 \%$ of reactions. Aftereffects of gathered square measure talked regarding beneath.

\section{Respondent Demographics}

The Statistical description of respondents showed in Table 4. The outcomes show that solitary 7 of 30 respondents (18.9\%) had working encounters of 6 to 10 years. Be that as it may, the greater part of respondents for example 30 of 37 (81.1\%) respondents had working encounters over 10 years. This suggests respondents have sufficient experience to give dependable data relating time invade factors. As demonstrated in the table, a larger part (73\%) of the respondents had gotten a degree in structural building, 5.4\% with mechanical designing, $8.1 \%$ in electrical building and $13.5 \%$ other related control. This related control incorporates Quantity Surveyor, Architect and recognition affirmations. In terms of the task size dealt with by respondents, the outcomes show that the majority of the respondents experienced in taking care of enormous development ventures, for example, the agreement measure of task surpass RM 5 million [6].

Table 5 demonstrates that respondents positioned "Income and budgetary troubles looked by contractual people in the predominant role with mean role of 13.8. PMC accepts this problem is primary the place it would possibly influence special causes, for example, contractual people terrible website the executives, lack of website employees and insufficient arranging and booking. Settling this problem ought to settle extraordinary troubles at the same time. Different examinations have indicated that in standpoint on consultants" income and money associated challenges of transient employee assume quintessential job in the time execution and deferral of venture, [2] learn about in Ghana referenced that temporary worker's money associated troubles have been located as 0.33 and profits during development were positioned that fifth giant issue influencing improvement time. 
Table 3. The top ten analysis responses by using all selected respondents.

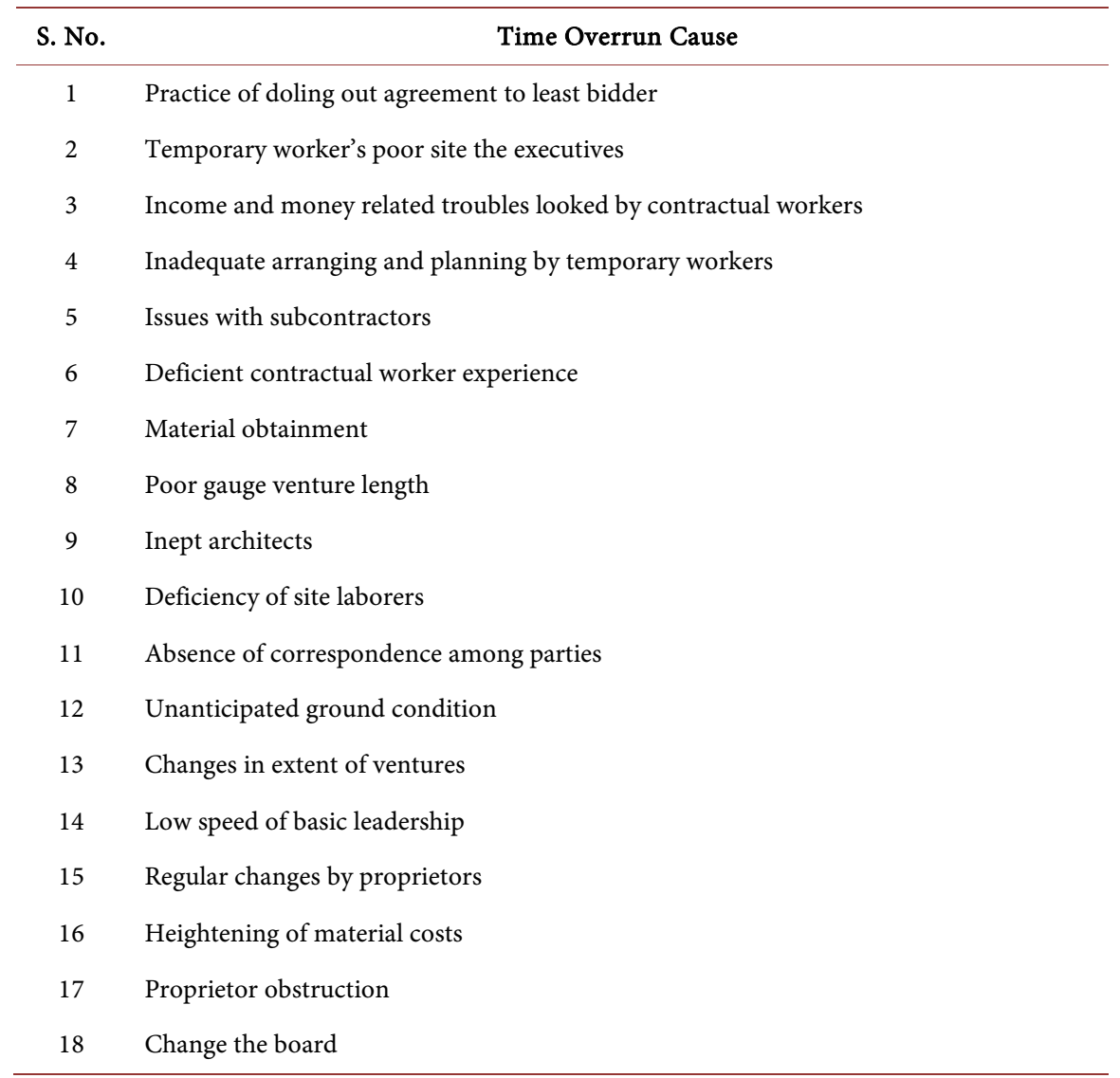

Table 4. Respondents demographic.

\begin{tabular}{cccc}
\hline & Frequency & Percent & Cumulative Percent \\
\hline Experiences & 7 & 18.9 & 18.9 \\
\hline - 10 Years & 30 & 81.1 & 100 \\
Above 10 Years & & & \\
\hline Respondent Specialization & 27 & 73.0 & 73.0 \\
\hline Civil Engineering & 2 & 5.4 & 78.4 \\
Mechanical Engineering & 3 & 8.1 & 100 \\
Electrical Engineering & 5 & 13.5 & \\
Other & & & 13.5 \\
Project Size & 5 & 13.5 & 100 \\
\hline 10 - 50 Million & 32 & 86.5 & \\
Above 50 Million & & & \\
\hline
\end{tabular}

\section{Conclusion}

By utilizing the past examination, this investigation can distinguish the elements that happen in each period of the venture life cycle. In large setting, just two components happened in all stages. Among these elements is the absence of 
Table 5. Time overrun ranking cause by PMC.

\begin{tabular}{lcc}
\hline \multicolumn{1}{c}{ Cause of Time Overrun } & Mean Rank & Rank \\
\hline Income and money related troubles looked by temporary workers & 13.8 & 1 \\
Contractual worker's poor site the board & 12.74 & 2 \\
Insufficient contractual worker experience & 12.61 & 3 \\
Lack of site laborers & 12.36 & 4 \\
Insufficient arranging and booking by temporary workers & 12.18 & 5 \\
Acceleration of material costs & 11.27 & 6 \\
Practice of appointing agreement to most reduced bidder & 11.01 & 7 \\
subcontractors Issues & 10.47 & 8 \\
Absence of correspondence among parties & 10.32 & 9 \\
Change the board & 9.69 & 10 \\
Late in material acquirement & 9.66 & 11 \\
Awkward fashioners & 9.46 & 12 \\
Poor gauge venture span & 8.07 & 13 \\
Low speed of basic leadership & 6.11 & 14 \\
Unanticipated ground condition & 6 & 15 \\
Changes in extent of ventures during development work & 5.93 \\
Successive structure changes & 5 & 16 \\
Proprietor impedance in development work/process & 4.31 & 17 \\
\hline & & 18 \\
\hline
\end{tabular}

correspondence among gatherings and change in the extent of the undertaking. From these outcomes, once more, it is noticed that development stage is a significant benefactor on schedule and cost invade in development venture. The discoveries could assist the professionals with gaining better comprehension about the components impacting on schedule and cost along development venture.

\section{Conflicts of Interest}

The authors declare no conflicts of interest regarding the publication of this paper.

\section{References}

[1] Fong, N.K., Wong, L.Y. and Wong, L.T. (2006) Fire Services Installation Related Contributors of Construction Delays. Building and Environment, 41, 211-222. https://doi.org/10.1016/j.buildenv.2005.01.004

[2] Frimpong, Y., Oluwoy, J. and Crawford, L. (2003) Causes of Delay and Cost Overruns in Construction of Groundwater Projects in a Developing Country: Ghana as a Case Study. International Journal of Project Management, 21, 321-326. https://doi.org/10.1016/S0263-7863(02)00055-8

[3] Kaliba, C., Muya, M. and Mumba, K. (2009) Cost Escalation and Schedule Delays in Road Construction Projects in Zambia. International Journal of Project Manage- 
ment, 27, 522-531. https://doi.org/10.1016/j.ijproman.2008.07.003

[4] Kaming, P., Olomolaiye, P., Holt, G. and Harris, F. (1997) Factors Influencing Construction Time and Cost Overruns on High-Rise Projects in Indonesia. Construction Management and Economics, 15, 83-94. https://doi.org/10.1080/014461997373132

[5] Abdul Rashid, K. (2002) Construction Procurement in Malaysia. International Islamic University Malaysia, Selangor, Malaysia.

[6] Abdullah, M.R., Abdul Azis, A.A. and Abdul Rahman, I. (2009) Causes of Delay and Its Effects in Large MARA Construction Project. International Journal of Integrated Engineering (Issue on Mechanical, Materials and Manufacturing Engineering).

[7] Al-Khalil, M.I. and Al-Ghafly, M.A. (1999) Delays in Public Utility Projects in Saudi Arabia. International Journal of Project Management, 17, 101-106. https://doi.org/10.1016/S0263-7863(98)00020-9

[8] Assaf, S. and Al-Hejji, S. (2006) Causes of Delay in Large Construction Projects in Saudi Arabia. International Journal of Project Management, 24, 349-357. https://doi.org/10.1016/j.ijproman.2005.11.010

[9] Chan, D.W.M. and Kumaraswamy, M.M. (1997) A Comparative Study of Causes of Time Overruns in Hong Kong Construction Projects. International Journal of Project management, 15, 55-63. https://doi.org/10.1016/S0263-7863(96)00039-7

[10] CIDB (2007) Construction Industry Master Plan (CIMP) 2006-2015.

[11] El-Razek, M.E.A., Bassioni, H.A. and Mobarak, A.M. (2008) Causes of Delay in Building Construction Projects in Egypt. Journal of Construction Engineering and Management, 134, 831-841. https://doi.org/10.1061/(ASCE)0733-9364(2008)134:11(831)

[12] Le-Hoai, L., Lee, Y.D. and Lee, J.Y. (2008) Delay and Cost Overruns in Vietnam Large Construction Projects: A Comparison with Other Selected Countries. KSCE Journal of Civil Engineering, 12, 367-377. https://doi.org/10.1007/s12205-008-0367-7

[13] Long, N.D., Ogunlana, S., Quang, T. and Lam, K.C. (2004) Large Construction Projects in Developing Countries: A Case Study Vietnam. International Journal of Project Management, 22, 553-561. https://doi.org/10.1016/j.ijproman.2004.03.004

[14] Mansfield, N.R., Ugwu, O.O. and Doran, T. (1994) Causes of Delay and Cost Overruns in Nigerian Construction Projects. International Journal of Project Management, 12, 254-260. https://doi.org/10.1016/0263-7863(94)90050-7

[15] Meepol, S. and Ogunlana, S.O. (2006) Factors Affecting Cost and Time Performance on Highway Construction Projects: Evidence from Thailand. Journal of Financial Management of Property and Construction, 11, 3-20. https://doi.org/10.1108/13664380680001076

[16] Odeh, A.M. and Battaineh, H.T. (2002) Causes of Construction Delay: Traditional Contracts. International Journal of Project Management, 20, 67-73. https://doi.org/10.1016/S0263-7863(00)00037-5

[17] Ofori, G. (1990) The Construction Industry; Aspects of Its Economics and Management. Singapore University Press, Singapore.

[18] Ogunlana, S.O. and Promkuntong, K. (1996) Construction Delays in a Fast-Growing Economy: Comparing Thailand with Other Economies. International Journal of Project Management, 14, 37-45. https://doi.org/10.1016/0263-7863(95)00052-6

[19] Rwelamilla, P.D. and Hall, K.A. (1995) Total Systems Intervention: An Integrated Approach to Time, Cost and Quality Management. Construction Management and 
Economics, 13, 235-241. https://doi.org/10.1080/01446199500000027

[20] Achermann, F., Eden, C. and Williams, T. (2005) Analyzing Project Cost Overruns: Comparing the Measured Mile Analysis and System Dynamics Modeling. International Journal of Project Management, 23, 135-139.

https://doi.org/10.1016/j.ijproman.2004.07.006

[21] Aibinu, A.A. and Jagboro, G.O. (2004) The Effects of Construction Delays on Project Delivery in Nigerian Construction Industry. International Journal of Project Management, 20, 593-599. https://doi.org/10.1016/S0263-7863(02)00028-5

[22] Al-Gahtani, K. and Mohan, S. (2007) Total Float Management for Delay Analysis. Journal of Cost Engineering, 49, 32-37.

[23] Assaf, S. (2006) Causes of Delay in Large Building Construction Projects. Journal of Management in Engineering, 11, 45-50. https://doi.org/10.1061/(ASCE)0742-597X(1995)11:2(45)

[24] Chimwaso, K.D. (2006) An Evaluation of Cost Performance of Public Projects; Case of Botswana. Department of Architecture and Building Services. Private Bag 0025, Gaborone, Botswana. Creative Research Systems.

[25] Kessing S. (2010) Delay in Joint Projects. Report Prepared in Freie University Berlin and European University Institute.

[26] Ogunlana, S. and Olomolaiye, P. (2005) Construction Delays in a Developing Economy: Comparing Nigeria with Other Economics. International Journal of Project Management, 14, 37-45. https://doi.org/10.1016/0263-7863(95)00052-6

[27] Lo, T., Fung, I. and Tung, K. (2006) Construction Delay in Hong Kong Civil Engineering Projects. Journal of ConstructionEngineering and Management, 132, 636-649. https://doi.org/10.1061/(ASCE)0733-9364(2006)132:6(636) 
M. Ilyas et al.

Appendix A. List of project facing time overrun.

\begin{tabular}{|c|c|c|c|c|c|}
\hline No. & Project Name & $\begin{array}{l}\text { Cost of Project } \\
\text { (Million RM) }\end{array}$ & $\begin{array}{c}\text { Duration of } \\
\text { Project (days) }\end{array}$ & $\begin{array}{l}\text { Overrun of } \\
\text { Time (Days) }\end{array}$ & $\begin{array}{l}\text { \%Time } \\
\text { Overrun }\end{array}$ \\
\hline \multicolumn{6}{|c|}{ PERAK State } \\
\hline 1 & MRSM Kroh Construction, & 33.6 & 504 & 335 & 66.47 \\
\hline 2 & MRSM Kuala Kangsar Construction, Perak & 40.3 & 545 & 4 & 0.73 \\
\hline 3 & Enlarge/Upgrade of IKM Lumut, Perak & 11.2 & 700 & 35 & 5 \\
\hline 4 & KKTM Lenggong Construction, Perak & 113.3 & 791 & 21 & 2.65 \\
\hline 5 & Development Winh System Fixing, MIMET & 1.3 & 265 & 68 & 25.66 \\
\hline \multicolumn{6}{|c|}{ SELANGOR State } \\
\hline 6 & MRSM Construction, Tanjung Karang, Selangor & 47.9 & 503 & 326 & 64.81 \\
\hline 7 & Latest GMI field Construction & 333.2 & 910 & 7 & 0.77 \\
\hline 8 & MFI field Enlargement, Bangi & 13 & 545 & 194 & 35.6 \\
\hline 9 & MSI attachment workshop Construction, Kulim & 1.8 & 168 & 76 & 45.24 \\
\hline 10 & FDRC at Fitec Construction & 1.6 & 84 & 2 & 2.38 \\
\hline \multicolumn{6}{|c|}{ PAHANG State } \\
\hline 11 & MRSM Construction, Pekan, Pahang & 48.5 & 671 & 153 & 22.8 \\
\hline 12 & MRSM Construction, Bentong. Pahang & 55 & 504 & 76 & 15.08 \\
\hline 13 & MRSM Upgrading, Kuala Lipis & 3.6 & 349 & 4 & 1.15 \\
\hline 14 & KKTM Kuantan, Pahang Construction & 66.4 & 728 & 256 & 35.16 \\
\hline \multicolumn{6}{|c|}{ TERENGGANU State } \\
\hline 15 & MRSM Kuala Terengganu Upgrade & 2.8 & 279 & 332 & 119 \\
\hline 16 & IKM Kemaman, Terengganu Construction & 67 & 713 & 18 & 2.52 \\
\hline 17 & Construction of one Unit PMN Banglo, Terengganu & 0.3 & 219 & 84 & 38.36 \\
\hline \multicolumn{6}{|c|}{ Territory State } \\
\hline 18 & MRSM Betong, Sarawak Construction & 42.6 & 728 & 34 & 4.67 \\
\hline 19 & MRSM Mukah, Sarawak Construction & 48 & 727 & 203 & 27.92 \\
\hline 20 & NEGERI SEMBILAN State & & & & \\
\hline 21 & Upgrade of MRSM Kuala Klawang, Negeri Sembilan & 13.0 & 909 & 66 & 7.26 \\
\hline \multicolumn{6}{|c|}{ KELANTAN State } \\
\hline 22 & MRSM Tumpat, Kelantan Construction & 48.7 & 538 & 127 & 23.61 \\
\hline \multicolumn{6}{|c|}{ PERLIS State } \\
\hline 23 & MRSM Arau, Perlis Construction & 38.6 & 727 & 241 & 33.15 \\
\hline \multicolumn{6}{|c|}{ Sabah State } \\
\hline 24 & MRSM Sandakan, Sabah Construction & 87.5 & 700 & 31 & 4.43 \\
\hline \multicolumn{6}{|c|}{ MELAKA State } \\
\hline 26 & Enlargement/Upgrade of IKM Jasin, Melaka & 47 & 364 & 138 & 37.91 \\
\hline 27 & Kolej Professional MARA Tiang Dua Construction & 29.8 & 504 & 213 & 42.26 \\
\hline \multicolumn{6}{|c|}{ JOHOR State } \\
\hline 28 & IKM Sri Gading, Johor Construction & 72.9 & 511 & 273 & 53.42 \\
\hline 29 & IKM Johor Bharu, Johor Enlargement & 9.4 & 413 & 263 & 63.68 \\
\hline 30 & IKM Muar, Johor Construction & 64.3 & 728 & 55 & 7.55 \\
\hline & Min. Time Overrun & & & \multicolumn{2}{|c|}{ two days } \\
\hline & Max. Time Overrun & & & \multicolumn{2}{|c|}{335 days } \\
\hline & Avg. Time Overrun & & & \multicolumn{2}{|c|}{23.74 percentage $(\%)$} \\
\hline
\end{tabular}

